\title{
Zymosan phagocytosis by mouse peritoneal macrophages is increased by apoHDL- and not by intact HD L-covered particles
}

M.D.T. Carvalho ${ }^{1}$,

V.E. Tobias ${ }^{1}$,

C.M.V. Vendrame?

A.F.M. Shimabukuro ${ }^{1}$,

M. Gidlund ${ }^{3}$ and

E.C.R. Q uintão ${ }^{1}$
Laboratórios de ${ }^{1}$ Lípides and 2 Imunopatologia da Esquistossomose, and ${ }^{3}$ Departamento de Patologia, Faculdade de Medicina, U niversidade de São Paulo, São Paulo, SP, Brasil

\section{Correspondence \\ E.C.R. Q uintão \\ Laboratório de Lípides \\ Faculdade de Medicina, USP \\ Av. Dr. Arnaldo, 455, s/3317 \\ 01246-903 São Paulo, SP \\ Brasil \\ Fax: + 55-11-852-1255 \\ E-mail: lipideq@usp.br}

This research was supported in part by FAPESP (M G 99/00158-4).

Received July 16, 1999

Accepted January 14, 2000

\section{Abstract}

The uptake of lipids and lipoprotein particles by macrophages undergoes phagocytic activation and the formation of foam cells are key events in atherosclerosis. In this study we determined how intact high density lipoproteins (HDL) and apolipoproteins-HDL (removal of the lipid component from HDL, i.e., apoHDL) influence the phagocytosis of zymosan by mouse peritoneal macrophages. Zymosan particles preincubated together with lipoproteins or alone (control) were incubated with the macrophages. Phagocytosis activity was reported as the percent of macrophages that internalized three or more zymosan particles. HDL co-incubated with zymosan did not influence the overall uptake of zymosan particles compared to apoHDL, which greatly enhanced the ability of the particle to be phagocytized $(\mathrm{P}<0.001)$. Part of this effect might be related to a greater binding of apoHDL to the particles compared to that of HDL $(\mathrm{P}<0.05)$. We conclude that this can be a useful method to study the ability of lipoproteins, including modified lipoproteins obtained from subjects with genetic forms of hyperlipidemia, to opsonize particles such as red blood cells and thus to investigate the processes that control the formation of foam cells and the mechanisms of atherogenesis.

Macrophages play a central role in the recognition, internalization, and degradation of cell ghosts (1). The phagocytic process in monocytes-macrophages represents a fundamental biological mechanism whereby lipoprotein molecules from biological tissue and fluids are rapidly internalized $(2,3)$. In most cases this is beneficial for the organism but in some cases may contribute to the pathogenesis of an inflammatory disease. In this regard, mononuclear phagocytes play a major role in atherogenesis, where monocytederived macrophages and macrophage-derived foam cells in the arterial tissue undergo phagocytic activation (4).

A key event in atherosclerosis is the formation of lipid-laden foam cells resulting from the uptake of lipoproteins by resident macrophages at the arterial intima level (2), although not all the mechanisms involved 
are fully understood. For instance, several studies suggest that high density lipoproteins (HDL) have anti-atherogenic properties which very probably involve their capacity to remove cell cholesterol (5). The role of these lipoproteins in phagocytosis has been investigated to a lesser extent (6). To study the phagocytic process we have used an assay that measures the uptake of inert zymosan particles by mouse peritoneal macrophages and demonstrates how this is modified by intact HDL and by apolipoproteins-HDL (apoHDL).

The uptake of zymosan by macrophages has been classified as nonspecific phagocytosis, and this characteristic has been used to distinguish it from receptor-mediated uptake of ligands such as immunoglobulin $\mathrm{G}$ ( $\mathrm{IgG})$ or complement $(7,8)$. The interaction of coated zymosan particles with cells also involves a number of important biological functions such as superoxide generation, which may oxidize low density lipoproteins (LDL) and HDL, the release of a variety of enzymes, and phagocytosis $(9,10)$.

HDL $(\mathrm{d}=1.063-1.21 \mathrm{~g} / \mathrm{ml})$ from plasma of healthy volunteer blood donors was isolated by sequential preparatory ultracentrifugation (11). ApoHDL was prepared by extracting the HDL preparation with pre-cooled $\left(-20^{\circ} \mathrm{C}\right)$ diethyl ether-ethanol $(3: 2 \mathrm{v} / \mathrm{v})$ and further processed as described in Ref. 12. This procedure resulted in a $96 \%$ reduction of the lipid content.

Resident mouse peritoneal exudates were used as source of macrophages. The cells

Figure 1 - Phagocytosis assay. Phagocytic macrophages were identified as cells that internalized three or more zymosan particles. The identification of phagocytosis in a typical experiment is indicated by arrows. Macrophages were stained with Leishman solution (13). Magnification, 400X; bar represents 10 $\mu \mathrm{m}$.

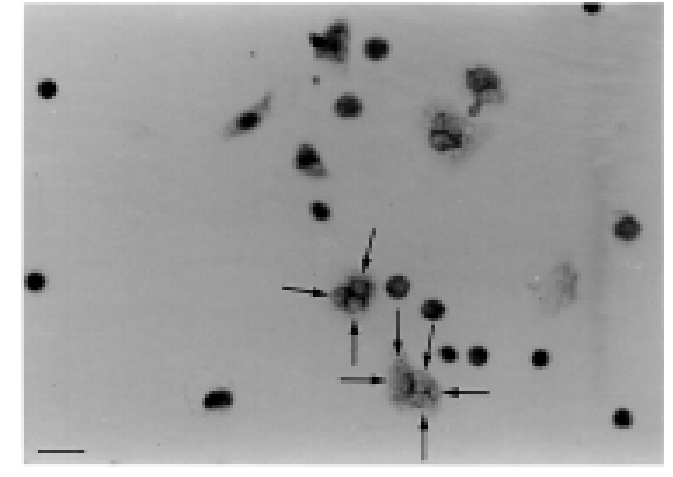

were harvested from mice in phosphate-buffered saline (PBS), $\mathrm{pH}$ 7.4, and washed twice in PBS, and their concentration was adjusted with RPMI 1640 medium containing antibiotics (13).

The percentage of phagocytized particles was determined by the method of Miller (14). Briefly, $10^{6}$ cells in $1 \mathrm{ml}$ RPMI 1640 were placed on coverslips in Leighton tubes and preincubated at $37^{\circ} \mathrm{C}$ for $30 \mathrm{~min}$ in a humidified $5 \% \mathrm{CO}_{2}$ atmosphere. Non-bound cells were removed by washing. Meanwhile, $10^{7}$ zymosan particles in $1 \mathrm{ml}$ RPMI 1640 were preincubated at $37^{\circ} \mathrm{C}$ for $30 \mathrm{~min}$ with either $10 \mathrm{mg}$ protein/ $\mathrm{ml}$ of intact HDL or apoHDL. Zymosan particles preincubated together with lipoproteins or zymosan particles alone (control) were added to the cells that adhered to the coverslips and incubated for an additional $30 \mathrm{~min}$ at $37^{\circ} \mathrm{C}$ in a humid $5 \% \mathrm{CO}_{2}$ atmosphere. The coverslips were then washed with pre-warmed RPMI 1640 medium to remove excess particles, stained with Leishman solution (15) and read under the light microscope. The ANOVA test was used for statistical comparison of the percentage of macrophages that phagocytized zymosan particles; a 0.05-confidence level was considered significant.

The phagocytosis of zymosan targeted for removal by macrophages is a two-step process initiated by its recognition and binding, followed by internalization (16). Due to this sequence the number of phagocytic macrophages was defined as the number of cells that internalized three or more zymosan particles. The results were then reported as percent phagocytic macrophages. At least 100 cells were counted on each coverslip. The visual identification of phagocytosis by 2 macrophages in a typical experiment is indicated by arrows in Figure 1.

Zymosan particles $\left(10^{8}\right)$ were incubated with HDL or apoHDL $(10 \mathrm{mg} / \mathrm{ml})$ or with no addition (control) at $37^{\circ} \mathrm{C}$ for $30 \mathrm{~min}$. After incubation the particles were washed extensively with RPMI 1640, and the HDL or 
apoHDL protein content was determined by the method of Lowry et al. (17). The results are reported as $\mu \mathrm{g}$ protein coated $/ 10^{8}$ zymosan particles. The coated amounts of apoHDL and of HDL were compared by the Student $t$ test; a 0.05-confidence level was considered significant.

The pooled data from 5 independent experiments using different preparations of HDL and apoHDL are shown in Table 1. It can be seen that when apoHDL was used there was a significantly higher percent of macrophages presenting phagocytosis. This was seemingly due to the fact that $80 \%$ more protein is available in zymosan as apoHDL than as intact HDL. In this regard, as compared to intact LDL, intact $\mathrm{HDL}_{3}$ has relatively more protein and is more efficient in stimulating erythrocyte phagocytosis through the $\mathrm{Fc}$ receptor (18).

By using zymosan particles preincubated with lipoproteins we could demonstrate the different biological effects of HDL and of apoHDL on the capacity of macrophages to promote phagocytosis. Furthermore, this method could be used to determine how these lipoproteins, including modified lipoproteins such as oxidized LDL, interfere with the phagocytosis of bacterial and viral pathogens, damaged or senescent cells (19), and cell ghosts (16).

\section{References}

1. Bennett MR, Evan GI \& Schwartz SM (1995). Apoptosis of human vascular smooth muscle cells derived from normal vessels and coronary atherosclerotic plaques. J ournal of Clinical Investigation, 95: 2266-2274.

2. Ross R (1999). Atherosclerosis - an inflammatory disease. New England J ournal of Medicine, 340: 115-126.

3. Khoo J C, Miller E, Pio F, Steinberg D \& Witztum J L (1992). Monoclonal antibodies against LDL further enhance macrophage uptake of LDL aggregates. Arteriosclerosis and Thrombosis, 12: 1258-1266.

4. Dentain C, Lesnik P, Chapman MJ \& Ninio E (1996). Phagocytosis activation induces formation of platelet activating factor in
Table 1 - Effect of preincubated zymosan (Zy) particles with intact HDL and apoHDL on their phagocytosis by mouse peritoneal macrophages.

Data are reported as means \pm SD for 5 experiments in which $\mathrm{N}=5$ coverslips were used in each group, and for which two different preparations of intact HDL and apoHDL were used. Phagocytic activity is reported as the percent of macrophages that internalized three or more Zy particles (see Figure 1). *P<0.001 for apoHDL compared to zymosan alone or to HDL (ANOVA). The mean concentrations of HDL and apoHDL protein-coated Zy particles were obtained by the method of Lowry et al. (17). Results are reported as $\mu \mathrm{g}$ protein coated $/ 10^{8} \mathrm{Zy}$. $+\mathrm{P}<0.05$ for apoHDL compared to HDL (Student t-test).

\begin{tabular}{lcc}
\hline Groups & $\begin{array}{c}\text { Phagocytic } \\
\text { activity (\%) }\end{array}$ & $\begin{array}{c}\mu \mathrm{g} \text { Protein coated/ } \\
10^{8} \text { particles }\end{array}$ \\
\hline $\begin{array}{l}\text { Untreated } \\
\text { zymosan }\end{array}$ & $23.6 \pm 1.9$ & - \\
HDL & $23.6 \pm 4.6$ & $10.1 \pm 2.2$ \\
ApoHDL & $40.6 \pm 1.0^{*}$ & $18.7 \pm 3.6^{+}$
\end{tabular}

\section{Acknowledgments}

We thank Mrs. S. Poppe and Ms. L.M. Harada for excellent technical assistance, and Dr. H. Goto for helpful criticism. The zymosan particles were a gift from the Allergy and Immunopathology Laboratory at the São Paulo Medical School, Brazil. human monocyte derived macrophages and in macrophage-derived foam cells. Relevance to the inflammatory reaction in atherogenesis. European J ournal of Biochemistry, 236: 48-55.

5. Kruth HS, Skarlatos SI, Gaynor PM \& Gamble W (1994). Production of cholesterol-enriched nascent high density lipoprotein by human monocyte-derived macrophages is a mechanism that contributes to macrophage cholesterol efflux. J ournal of Biological Chemistry, 269: 2451124518.

6. Atger V, Giral P, Simon A, Cambillau M, Leveson J, Gariepy J, Megnien J L \& M oatti N (1995). High-density subfractions as markers of early atherosclerosis. A- merican J ournal of Cardiology, 75: 127131.

7. Sung SJ, Nelson RS \& Silverstein SC (1983). Yeast mannans inhibit binding and phagocytosis of Zymosan by mouse peritoneal macrophages. J ournal of Cell Biology, 96: 160-166.

8. Balsinde J , Fernández B, Solís-Hernuzo J A $\&$ Diez E (1992). Pathways for arachidonic acid mobilization in zymosan-stimulated mouse peritoneal macrophages. Biochimica et Biophysica Acta, 1136: 75-82.

9. Melamed J, Medicus RG, Amaout MA \& Colten HR (1983). Induction of granulocyte histaminase release by particle bound complement $\mathrm{C} 3$ cleavage products (C3b, C3bi) and IgG. J oumal of Immunol- 
ogy, 131: 439-444.

10. Xing X, Baffic J \& Sparrow CP (1998). LDL oxidation by activated monocytes: characterization of the oxidized LDL and requirement for transition metal ions. J ournal of Lipid Research, 39: 2201-2208.

11. Havel RJ , Eder HA \& Gragdon J H (1955). The distribution and chemical composition of ultracentrifugally separated lipoproteins in human serum. J ournal of Clinical Investigation, 34: 345-353.

12. Gillett MPT \& Owen J S (1992). Comparison of the cytolytic effects in vitro on Trypanosoma brucei brucei of plasma, high density lipoproteins, and apolipoprotein A-I from hosts both susceptible (cattle and sheep) and resistant (human and baboon) to infection. J ournal of Lipid Re- search, 33: 513-523.

13. Fuhrman $\mathrm{R}$, J udith $\mathrm{O}$, Keidar $\mathrm{S}$, Ben-Yaish L, Kaplan M \& Arivan M (1997). Increased uptake of LDL by oxidized macrophages is the result of an initial enhanced LDL receptor activity and of a further progressive oxidation of LDL. Free Radical Biology and Medicine, 23: 34-46.

14. Miller ME (1969). Phagocytosis in the newborn infant: humoral and cellular factors. J ournal of Pediatrics, 74: 255-259.

15. Moura RA (1982). Técnicas de Laboratório. 2 nd edn. Livraria Atheneu Ltda., Rio de J aneiro, RJ , Brazil.

16. Sambrano GR, Terpstra $V \& \&$ Steinberg $D$ (1997). Independent mechanisms for macrophage binding and macrophage phagocytosis of damaged erythrocytes.
Arteriosclerosis, Thrombosis, and Vascular Biology, 17: 3442-3448.

17. Lowry $\mathrm{OH}$, Rosebrough $\mathrm{NJ}$, Farr $\mathrm{AL} \&$ Randall RJ (1951). Protein measurement with the folin phenol reagent. J ournal of Biological Chemistry, 193: 265-275.

18. Bigler RD, Khoo M, Lund-Katz S, Scerbo L \& Esfahani M (1990). Identification of low density lipoprotein as a regulator of $\mathrm{FC}$ receptor-mediated phagocytosis. Proceedings of the National Academy of Sciences, USA, 87: 4981-4985.

19. Krieger M (1997). The other side of scavenger receptors: pattern recognition for host defense. Current Opinion in Lipidology, 8: 275-280. 